\title{
Effectiveness of the GAEC cross-compliance standard Ploughing in good soil moisture conditions in soil structure protection
}

\author{
Maria Teresa Dell'Abate, ${ }^{1}$ Paolo Bazzoffi, ${ }^{2}$ Arianna Ciancaglini, ${ }^{2}$ Rosa Francaviglia, ${ }^{1}$ \\ Carlo Galeffi, ${ }^{1}$ Rosario Napoli, ${ }^{1}$ Ulderico Neri, ${ }^{1}$ Bruno Pennelli ${ }^{1}$ \\ ${ }^{1}$ CRA-RPS Centro di ricerca per lo studio delle relazioni tra pianta e suolo, Roma; ${ }^{2}$ CRA-ABP \\ Centro di ricerca per l'agrobiologia e la pedologia, Firenze, Italy
}

\begin{abstract}
Researches have been carried out within the framework on the EFFICOND ${ }^{1}$ Project, focused at evaluating the effectiveness of the
\end{abstract}

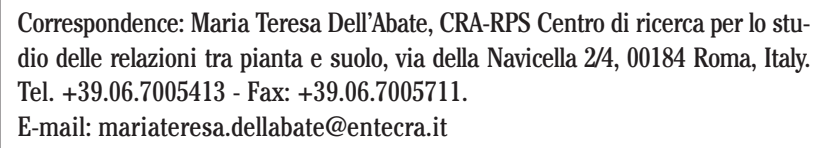

E-mail: mariateresa.dellabate@entecra.it

Key words: soil moisture conditions, GAEC standard, cross-compliance.

Acknowledgements: experimental trials were performed in the different CRA farms under the responsibility of the following colleagues, who carried our periodical soil samples and provided also information on the study area and the agronomical data presented in this paper. We wish to thank all of them for their valuable collaboration: Cesare Tomasoni and Lamberto Borrelli (CRA-FLC); Antonio Melchiorre Carroni and Mauro Salis (CRA-AAM); Roberta Farina, Salvatore Antonio Colecchia and Antonio Troccoli (CRACER); Paolo Bazzoffi and Arianna Ciancaglini (CRA-ABP); Ulderico Neri, Carlo Galeffi and Bruno Pennelli (CRA-RPS). Thanks are due also to Alessandro Marchetti (CRA-RPS) for his help in statistical analysis.

The research was made possible by CRA and MiPAAF funding. Carlo Galeffi (RPS) and Arianna Ciancaglini (ABP) were the recipients of research grants within the EFFICOND project.

Contributions: MTDA, RPS research supervisor and laboratory guidance, results analysis and comment, text writing, bibliographic research; UN, experimental trial at RPS farm managing, bibliographic research, collaboration at text writing; RN, soil hydrological characterisation, data elaboration and comment, text writing; $\mathrm{PB}$, set up of experimental design and selection of experimental areas, research guidance as leader of the EFFICOND project; RF, collaboration to data collection, comments and text writing; CG, RPS laboratory analysis (soil water retention curves), periodical soil sampling and field measurements, bibliographical research; AC, ABP laboratory analysis (aggregate stability measures), data analysis; BP, weed analysis and collaboration at RPS farm field measurements.

Received for publication: 25 March 2011.

Accepted for publication: 28 May 2011.

(C) Copyright M.T. Dell'Abate et al., 2011

Under no circumstances figures can be used without prior written consent of the copyright owner.

Licensee PAGEPress, Italy

Italian Journal of Agronomy 2011; 6(s1):e10

doi:10.4081/ija.2011.6.s1.e10

This work is licensed under a Creative Commons Attribution NonCommercial 3.0 License (CC BY-NC 3.0). standards of Good Agricultural and Environmental Conditions (GAECs) established for Cross Compliance implementation under EC Regulation 1782/2003. In particular the standard 3.1b deals with soil structure protection through appropriate machinery use, with particular reference to ploughing in good soil moisture conditions. The study deals with the evaluation of soil structure after tillage in tilth and notilth conditions at soil moisture contents other than the optimum water content for tillage. The Mean Weight Diameter (MWD) of water stable aggregates was used as an indicator of tillage effectiveness. The study was carried out in the period 2008-2009 at six experimental farms belonging to Research Centres and Units of the Italian Agricultural Research Council (CRA) with different pedo-climatic and cropping conditions. Farm management and data collection in the different sites were carried out by the local CRA researchers and technicians. The comparison of MWD values in tilth and no tilth theses showed statistically significant differences in most cases, depending on topsoil texture. On clay, clay loam, silty clay, and silty clay loam topsoils a general and significant increase of MWD values under no tilth conditions were observed. No significant differences were observed in silt loam and sandy loam textures, probably due to the weak soil structure of the topsoils. Moreover, ploughing in good soil moisture condition determined higher crop production and less weed development than ploughing in high soil moisture conditions.

\section{Introduction}

The need of an optimum water content for soil tillage mainly starts up from agronomical reasons, ranging from advantages due to reduction of both energy inputs and time required, to the improved seedbed preparation and the consequent higher yields. However, additional advantages taken from tillage at appropriate water contents are represented by the possibility to gain positive results in contrasting soil erosion and improving soil stability structure (Dexter, 2004a,b,c). A qualitative description of soil physical state in terms of ease of tillage, seedbed preparation, seedling emergence and root growth is qualitatively summarised in the tilth concept (SSSA, 1979; Brady, 1984; Plaster, 1985; Schjønning et al. 2007). 
A tilth index (TI) was initially developed using different models which consider a multiplicative combination of tilth factors such as bulk density, cone index, organic matter content, aggregate uniformity coefficient and plasticity index (Singh et al., 1992). However the relationship between degree of tillage and tilth was actually considered as highly qualitative since a systematic approach for relating tillage practice to physical conditions is still lacking (Tripathi et al., 2005). Thus it was modified with a model based on multiple linear regression of crop yield vs. various soil properties depending on soil type (Tripathi et al., 2005). Due to the complex and multifactor nature of the tilth condition, an increasing number of researches were carried out in order to move from a qualitative and subjective definition to an operative and standardised level through the proposition of various indices or parameters based on different approaches.

One approach, adopted by Dexter and collaborators during more than a decade, has been based on the water retention curves of soils, plotted as gravimetric water content against the natural logarithm of the pore suction in $\mathrm{hPa}$ (Dexter and Bird, 2001; Dexter and Birkas, 2004; Dexter et al., 2005; Keller et al., 2007). Since tillage at a certain water content produces the smallest amount of clods and large aggregates and the largest amount of small aggregates, this value is called the optimum water content for tillage, $\theta_{\text {OPT. }}$. It was initially found to be equal to the water content at the inflection point of the water retention curve as fitted with the van Genuchten (1980) equation (Dexter and Bird, 2001; Dexter et al., 2005). More recently, it was found that in most soils the pore size distribution follows a bi-modal equation and the optimum water content for tillage occurs when the matrix porosity is saturated, but the structural porosity is air filled (Dexter and Richard, 2009). The authors conclude that whereas the double-exponential function provides a better understanding of physical processes occurring in soil during tillage, it does not provide a better estimate of the optimum water content for tillage than the van Genuchten (1980) equation or of the size distribution of aggregates and clods estimated through the $S$ theory (Dexter and Birkas, 2004; Keller et al., 2007). In particular, the slope (S) of the water retention curve at its inflection point, when plotted against the matric water potential on a logarithmic scale, was proposed as an index of soil physical quality (Dexter, 2004a,b,c; Dexter and Czyz, 2007). This index was developed in order to foresee soil friability and workability from aggregate size distribution or tilth. Moreover, a theory was developed which includes $\mathrm{S}$ values within pedo-transfer functions to calculate soil hardsetting after drying (Dexter, 2004b) and represents a measure of soil micro-structural porosity (Dexter, 2004c). Reference values to discriminate soils having goods or poor structural quality were indicated around $\mathrm{S}=0.035$ (Dexter, 2004a) or $\mathrm{S}=0.036$ (Dexter and Birkas, 2004), whereas values $<0.020$ were attributed to soils with very poor physical conditions. $\mathrm{S}$ values generally increase when clay content and bulk density decrease and organic matter content increases. Relationships between $\mathrm{S}$ and the optimum water content for tillage, $\theta_{\mathrm{OPT}}$, were discussed by Keller et al. (2007). They found a positive correlation between the soil physical quality index $S$ and the specific surface area of the particles or aggregates obtained when ploughing at the soil water content corresponding to the inflection point of the soil water retention curve $\theta_{\mathrm{INFL}}$; since no aggregate with size $>50 \mathrm{~mm}$ was produced in soils with $\mathrm{S}>0.04$ tilled at the optimum water content for tillage, they concluded that the size distribution of soil aggregates produced after tillage can be estimated using the $\mathrm{S}$ value.

The range of water contents for tillage is usually narrow for high clay content soils and wider for soils with lower clay contents (Hoogmoed, 1985), being the range reduced by soil degradation. Soil workability has been related also to the water content corresponding to the lower plasticity limit (LPL) or to the upper plasticity limit (UPL) of Attemberg (Mueller, 1985; Dexter e Bird, 2001). Mueller et al. (2003) found that in certain soils with texture from sandy-silt to clay, the soil was too wet for an optimum tillage even if the soil water content corresponded to the inflection point of the water retention curve. It was proposed the use of correction factors as 0.9 LPL (Dexter and Bird, 2001) or 0.8 LPL (Keller et al., 2007), or to include in the water content calculation also the values corresponding to the upper plastic limit (UPL), according to Kretschmer (1996). Limits to this approach concern sandy soils, which are not plastic, and the non-applicability of PL measures to field conditions.

Finally, it was suggested to include also values of organic matter content into the pedo-transfer functions (PTF) used for estimating the maximum soil water content for optimum soil workability (Dexter and Bird, 2001).

Other authors (Kay et al., 2006) proposed the use of soil structural quality index based on biological processes, considering an optimum water range NLWR (non-limiting water range), which is highest when soil structural quality is high. The rationale of this index is based on the consideration that, when soil water content is comprised within the NLWR range, the rate of biological processes is similar for different soils subjected to similar environmental conditions.

The role of organic matter, in particular its labile fractions, as cementing factor in the formation and stabilisation of soil structure has been stressed recently by various authors. Schjønning et al. (2007) showed that a decrease of organic matter content in soil induced by management practices could determine conditions of tilth critical for tillage and that variations of organic matter content, clay dispersibility and expressions of soil biological activity can be early indicators of tilth condition variation. The same authors convey reservation about the use of wet aggregate stability measures as an isolated criterion when evaluating farming system effects on soil quality. In different soils having contrasting amounts of organic carbon and clay, it was shown (Dexter et al., 2008) that the amount of organic carbon bonded with clay correlates better with a number of soil physical characteristics (such as bulk density, soil structure, water retention and content of readily-dispersible clay) than total organic carbon.

The relation between the cohesive forces which determine aggregates in soil and the force required to their break-up is the basis of methods to determine soil aggregate stability and their dimensional distribution (Kemper and Rosenau, 1986; Rohošková and Valla, 2004; Le Bissonnais, 1996). Measures of soil aggregate stability show a very high correlation with the pore size dimension distribution and with field factors, among which tillage practices represent an important cause of disturbance that could contribute to aggregate break-down in field. Thus, the measure of aggregate stability is considered a first level index of soil structure condition in the field. In fact, the increase of aggregate stability, which in turn favours the conservation of a relative abundance of soil pores with adequate dimensions, besides to both good aeration and tilth, is associated to a decrease of soil erosion risk.

The application of the $\mathrm{S}$ index of soil physical quality to a number of soils in Sicily indicated that $70 \%$ of investigated soils showed $S$ values $<0.060$; moreover, $\mathrm{S}$ decreased with increasing values of clay amount, bulk density and soil erodibility factor K (Bagarello et al., 2009). In a Fluvisol where different crop rotations were compared (Armenise et al., 2008), a positive correlation was found also among the values of $S$ index, organic matter content, total nitrogen, and soil water contents at both field capacity and wilting point. In the agronomical practices adopted in Italy, the soil water condition at which the more favourable workability conditions occur is empirically determined and is called tilth, whereas the condition no tilth is empirically attributed at water contents outside such range. The hydrological conditions defined as field capacity, i.e. the condition where all excess water has drained away by gravity up to relatively stable residual soil water content, often correspond to a too moist soil condition for ploughing. Other agronomical phenomena sometimes observed in the field, when soil is tilled at very high water contents, is represented by the inversion of moist and 
dry layers, which can cause temporary (2-3 years) conditions of soil biological infertility, locally known by Italian farmers as arrabbiaticcio, caldafredda or verdesecca (Bonciarelli, 1981). As that condition occurs, weed development (e.g. Lolium temulentum, Papaver Rhoeas) predominates over crops, which are also more susceptible to pathogen attack. Tillage at non-optimum soil water conditions could occur when the harvest-time of the preceding crop is very close to the main tillage before the subsequent crop sowing. In such cases the knowledge of ranges of optimum water contents appropriate for specific soils could provide an operative indication to the farmers in order to successfully carry out agronomical operations respecting also environmental requirements.

In the last years, these issues were included among the environmental objectives of the CAP policy regarding the maintenance of soil physical and chemical quality characteristics following proper agricultural practices, leading to the set up of standards of Good Agricultural and Environmental Conditions (GAECs). For Cross Compliance implementation, in the Italian National Research Project EFFICOND, analysis of the environmental effectiveness of GAEC standards has been carried out. The Issue 3 deals with soil structure protection through appropriate machinery use, with particular reference to ploughing in good soil moisture conditions in the standard 3.1b. In the present paper, results of research carried out in different experimental area and soils in Italy are reported. The aim was to verify the effects of ploughing at different soil water contents on the maintenance of soil structure, and to find the optimum or the maximum values corresponding to different soil characteristics in order to minimize the effects of soil compaction and surface drainage. An ultimate and additional objective was to give an insight into the possibility to adopt a proper methodology to verify in the field the effectiveness of the GAEC standard 3.1b Ploughing in good soil moisture conditions. Measures of soil aggregate stability and size distribution, evaluated as aggregates mean weight diameter (MWD), were compared in different experimental theses with two different soil moisture levels, higher and lower than the upper soil tillage limit, according to the water retention curve function parameters. At the mean time, agronomical surveys on plant emergence, weed competition, and crop yields were carried out.

\section{Materials and Methods}

\section{Study areas and experimental design}

Researches were carried out at six experimental farms belonging to the following Research Centres of the Italian Agricultural Research Council (CRA), to compare the soil tillage effects at different water contents defined as tilth and no tilth, according to locally traditional and consolidated soil management practices.

\section{CRA-AAM}

Research Unit for Agro-pastoral Systems in Mediterranean Environment, experimental farm located in Sanluri (Medio Campidano, Sardinia), altitude $68 \mathrm{~m}$ a.s.l. The soil is a Vertic Haploxerept (Soil Survey Staff, 1999) derived from Holocene deposits, with a sandy-clay-loam texture ( $\mathrm{S}=45 \%, \mathrm{Si}=26 \%, \mathrm{C}=29 \%), 1.1 \%$ organic matter content, sub-alkaline reaction (7.4), available $\mathrm{P}_{2} \mathrm{O}_{5} 18 \mathrm{mg}$ $\mathrm{kg}^{-1}$, and exchangeable $\mathrm{K}_{2} \mathrm{O} 212 \mathrm{mg} \mathrm{kg}^{-1}$. Mean annual rainfall is 423 $\mathrm{mm}$, distributed on average in 54 rainy days; rainfall from November 2008 to June 2009 was $574 \mathrm{~mm}$, minimum monthly temperature $3.6^{\circ} \mathrm{C}$ in February 2009 (absolute minimum $-2.8^{\circ} \mathrm{C}$ ). The experimental design compared tilth and no tilth in three cropping systems: continuous durum wheat, durum wheat-fallow and durum wheat-Egyptian clover. Plots were ploughed by moldboard at $40 \mathrm{~cm}$ depth, and the seedbed was prepared with spike harrowing. Soil characterization and biomass accumulation were obtained by collecting samples from four different $25 \mathrm{~m}^{2}$ sampling areas randomly chosen alongside the plots $(5 \times 100 \mathrm{~m}$ each). Seed density in the first year was as follows: durum wheat (Triticum durum Desf.) cv. Simeto: $200 \mathrm{~kg} \mathrm{ha}^{-1}$; Egyptian clover (Trifolium alexandrinum L.) cv. Sacromonte: $30 \mathrm{~kg} \mathrm{ha}^{-1}$. In the second year only durum wheat with the same cultivar and seed density was sowed.

\section{CRA-ABP}

Research Centre for Agro-biology and Pedology, experimental farm of Fagna (Florence, Tuscany), Central Italy, altitude $225 \mathrm{~m}$ a.s.l. The soil is a Aquic Haplustept (Soil Survey Staff, 1999) derived from Pleistocene lacustrine deposits, with a clay texture $(\mathrm{S}=9 \%, \mathrm{Si}=38 \%, \mathrm{C}=53 \%), 1.6 \%$ organic matter content, and alkaline reaction (8.2). Mean annual rainfall is $1024 \mathrm{~mm}$, and mean temperature $13.4^{\circ} \mathrm{C}$. The experimental design compared tilth and no tilth on soft wheat (Triticum aestivum L.), and included only in 2008 the comparison between conventional tillage by moldboard at 20 and $40 \mathrm{~cm}$ depth (1820 and $\left.1584 \mathrm{~m}^{2}\right)$ and ripping $\left(1714 \mathrm{~m}^{2}\right)$.

\section{CRA-ABP}

Research Centre for Agro-biology and Pedology, experimental farm of Santa Elisabetta located in Vicarello di Volterra (Pisa, Tuscany), Central Italy, altitude $200 \mathrm{~m}$ a.s.l. The soil derives from Pliocene marine sediments, classified as Vertic Haploxerept (Soil Survey Staff, 1999). Average slope is $25 \%$, texture is silty-clay ( $\mathrm{S}=11 \%, \mathrm{Si}=42 \%, \mathrm{C}=47 \%$ ), with $1.5 \%$ organic matter content, and alkaline reaction (8.6). Mean annual rainfall is $678 \mathrm{~mm}$. The experimental design compared tilth and no tilth on common wheat (Triticum aestivum L.). The size of the two experimental plots was $1857.11 \mathrm{~m}^{2}$ and $2432.07 \mathrm{~m}^{2}$ respectively for the tilth and no tilth treatments. Harvesting was performed through a combine harvester over the entire plots.

\section{CRA-CER}

Research Centre for Cereal Crops (Foggia, Apulia), Southern Italy, altitude $79 \mathrm{~m}$ a.s.l. The soil is a clay-loam vertisol classified as Typic Calcixerert (Soil Survey Staff, 1999), with 35\% clay, 25\% sand and 40\% silt, $2.1 \%$ organic matter content, alcaline reaction (8.3), available $\mathrm{P}_{2} \mathrm{O}_{5}$ $41 \mathrm{mg} \mathrm{kg}^{-1}$, exchangeable $\mathrm{K}_{2} \mathrm{O} 1560 \mathrm{mg} \mathrm{kg}^{-1}$. The area is characterized by an average annual temperature of $15.8^{\circ} \mathrm{C}$, with monthly means ranging from $7.4^{\circ} \mathrm{C}$ in January to $25.5^{\circ} \mathrm{C}$ in August. Mean annual rainfall is $524 \mathrm{~mm}$, with $374 \mathrm{~mm}$ of mean rainfall during the growing season (November-June) of durum wheat. The experimental design in 2009 compared tilth and two levels of no tilth tillage, i.e. high water content in the topsoil vs high water content in the subsoil, on durum wheat (Triticum durum Desf.) cv. PR22D89 (Pioneer). Plots, $10 \mathrm{~m} \times 74 \mathrm{~m}$ and separated each other by a strip of $2 \mathrm{~m}$ of fallow soils, were ploughed by moldboard at $35-40 \mathrm{~cm}$ depth, and the seedbed was prepared with disk harrowing.

\section{CRA-FLC}

Research Centre for Fodder Crop and Dairy Productions, experimental farm situated in Montanaso Lombardo (Lodi, Lombardy), Northern Italy, altitude $80 \mathrm{~m}$ a.s.l. The soil is a Typic Haplustalf coarse-loamy, mixed, mesic (Soil Survey Staff, 1999), with a sandy-loam texture ( $\mathrm{S}=64 \%, \mathrm{Si}=24 \%, \mathrm{C}=12 \%$ ), $0.9 \%$ organic matter content, sub-acid reaction (5.2), available $\mathrm{P}_{2} \mathrm{O}_{5} 143 \mathrm{mg} \mathrm{kg}^{-1}$, exchangeable $\mathrm{K}_{2} \mathrm{O} 160 \mathrm{mg} \mathrm{kg}$. Mean annual rainfall is $800 \mathrm{~mm}$, and mean temperature of $12.2^{\circ} \mathrm{C}$ (Borrelli and Tomasoni, 2005). The experimental design compared tilth and no tilth tillage by moldboard at $30 \mathrm{~cm}$ depth, and the seedbed was prepared with vertical rotary harrowing. Soft wheat (Triticum aestivum L.) cv. Aubusson was sown with a seed density of $200 \mathrm{~kg} \mathrm{ha}^{-1}$ and the 
harvesting was performed with plot combine. The trial surface was $1000 \mathrm{~m}^{2}\left(500 \mathrm{~m}^{2}\right.$ for tilth and $500 \mathrm{~m}^{2}$ for no tilth) and three subsampling for each thesis were compared.

\section{CRA-RPS}

Research Centre for the Soil-Plant System, experimental farm located in Tor Mancina (Rome, Latium), Central Italy, altitude $43 \mathrm{~m}$ a.s.l. The soil is sloping (average slope 8\%, range 2-10\%), classified as Entic Lithic Haploxeroll derived from vulcanic materials and Mollic Palexeralf on colluvial deposits of vulcanic origin (Soil Survey Staff, 1999), with silty-loam texture ( $\mathrm{S}=31 \%, \mathrm{Si}=46 \%, \mathrm{C}=22 \%), 1.6 \%$ organic matter content, neutral reaction (6.7), and exchangeable $\mathrm{K}_{2} \mathrm{O} 189 \mathrm{mg} \mathrm{kg}^{-1}$. The subsoil is characterized by a duripan derived from tuffs at $30-45 \mathrm{~cm}$ of depth, containing leucitic minerals partially degraded to analcime (natural zeolite). The experimental design compared tilth tillage by moldboard at $40 \mathrm{~cm}$ depth at the end of the summer season, according to the usual local agricultural practice, and no tilth tillage at two levels of soil water content (high and very high). No tilth plots have been ploughed by moldboard at two depths: 20 and $40 \mathrm{~cm}$. All plots, total surface 2.43 ha, plot surface $4860 \mathrm{~m}^{2}(18 \mathrm{~m} \times 270 \mathrm{~m})$ have been tilled along the maximum slope, and soil samples collected in three altimetric zones for each plot (summit, intermediate and bottom) to allow evaluating the variability along the slope. Seedbed was prepared with disk harrowing, and durum wheat (Triticum durum Desf.) cv. Duilio was sown with a seed density of $210 \mathrm{~kg} \mathrm{ha}^{-1}$. Mean annual rainfall is $850 \mathrm{~mm}$, and during the experiment in 2008-2009 total rainfall was $250 \mathrm{~mm}$ higher in comparison with the mean value. As a consequence erosion processes due to water runoff in the no tilth plots have been enhanced. In particular total rainfall in the period November 2008-June 2009 was $830 \mathrm{~mm}$ and mean temperature $11.6^{\circ} \mathrm{C}$, minimum monthly temperature $5.8^{\circ} \mathrm{C}$ in January 2009, absolute minimum temperature $-5.6^{\circ} \mathrm{C}$ in February 2009 , monthly and absolute maximum temperature $21.5^{\circ} \mathrm{C}$ and $34.9^{\circ} \mathrm{C}$ respectively in June 2009.

\section{Soil sampling and field measures}

For each experimental plot a series of samples were collected for the determination of the soil water retention curve, in particular referred to the first topsoil horizon (the Ap horizon). The samples were collected inside the plots following the two main experimental theses of tilth and no tilth conditions during the three time periods of fal//winter 2008, spring/summer 2009 and fall/winter 2009, obtaining the total number of 185 samples and 433 replicates. The bulk density was measured for each plot and the two theses for each of the three time periods, by using the sampling core method (MiPAAF, ${ }^{2}$ 1997a method II.1).

\section{Materials and Methods}

Topsoil moisture contents for tilth and no tilth field conditions were measured by gravimetric method on disturbed samples taken immediately before ploughing. Moreover, in each plot undisturbed soil clods were collected, air dried and subjected to aggregates stability measures.

During plant growth cycle, some field measures were carried out, such as: plant emergence by visual control along transects randomly set upon the seeding rows; weeds sampling and classification into mono and dicotyledonous, and then also according to genus or species, and finally dry mass determination; harvest index and yield estimation.

${ }^{2}$ MiPAAF, Ministero delle Politiche Agricole Agroalimetari e Forestali.

\section{Laboratory determinations}

Water retention curve and hydrological characterization

According to the Italian standard official method (MiPAAF, 1997b), soil samples were collected from the field plots, air-dried and sieved ( $<2 \mathrm{~mm}$ ). Two replicates of each disturbed soil sample, previously saturated with de-mineralized water on ceramic plates and plastic membranes, were used for analyses of gravimetric water content $\left(\mathrm{gg}^{-1}\right)$ at four different $\mathrm{pF}$ values $(2.0,2.5,3.0,4.2)$ with a set of pressure extractors (Richard apparatus, Soilmoisture Equipment Co., USA). Samples were weighted, then drained to soil matric potential (h) of $-100,-333,-1000$ and $-15000 \mathrm{~cm}$. After applying the desired cell gas pressure, samples were allowed to come to equilibrium and weighted; when the equilibrium at the maximum pressure was reached, samples were re-weighed and the water contents were determined gravimetrically by drying the samples at $105^{\circ} \mathrm{C}$ for $24 \mathrm{~h}$. The water content at each pressure head $\theta(\mathrm{h})$ is expressed as a percentage of the oven dry weight of the soil with the formula (1):

$$
O(h)=\frac{W_{W}-W_{d}}{W_{d}} 100
$$

with $\mathrm{W}_{\mathrm{w}}=$ wet weight at pressure head $\mathrm{h}$, and $\mathrm{W}_{\mathrm{d}}=$ dry weight.

On the basis of water content measured at different water potential the water retention curve was plotted by fitting the parameters of van Genuchten function (van Genuchten, 1980), with the Mualem modification $m=(1-1 / n)$ (Mualem, 1976), through the RECT model (van Genuchten et al., 1991). To apply the fitting operation, some extra points were calculated by using the European pedotransfer functions (PTF) Hypres (Wösten et al., 1999), both in the range Field Capacity/Wilting Point and Saturation/Field Capacity, on the basis of soil texture (sand, silt, clay), bulk density and organic carbon content measured, as average for each experimental plot.

The water retention curve for each Ap horizon of each experimental plot was determined; the Optimum Tillage Limit $\left(\theta_{\text {oTL }}=\theta\right.$ INFL $)(2)$ and Upper Tillage Limit $\left(\theta_{\mathrm{UTL}}\right)(3)$ water contents were calculated according to Dexter and Bird (2001), by using the water retention curve function parameters $\theta_{\text {sat }}, \theta_{\text {res }}, \alpha, \mathrm{n}$ and $\mathrm{m}$; the water content levels corresponding to tilth and no tilth experimental conditions were transformed in volumetric water contents by using the bulk density measured on the field.

$$
\theta_{\text {NNFL }}=\left(\theta_{S A T}-\theta_{R E S}\right)\left[1+\frac{1}{m}\right]^{-m}+\theta_{R E S}
$$

$$
\theta_{U T L}=\theta_{I N F L}+0.4\left(\theta_{S A T}-\theta_{I N F L}\right)
$$

\section{Wet sieving aggregate stability}

Aggregates stability was evaluated by wet sieving, based on the principle that unstable aggregates will break down more easily than stable aggregates when immersed into water. Mean weight diameter of water stable aggregates was determined on macroaggregates of 7.93-4.75 mm diameter, obtained after drying at room temperature the soil core samples and breaking down into smaller mechanical aggregates using a rubber hammer. The samples, passed through 7.93 $\mathrm{mm}$ mesh and retained at $4.75 \mathrm{~mm}$ mesh, were used for determination of aggregate water-stability by using the apparatus and procedure described in Kemper and Rosenau (1986). MWD of water stable aggregates was determined according to van Bavel (1949) and carried out on three sub-samples for each replicate. The MWD was deter- 
mined on $25 \mathrm{~g}$ of soil dry aggregates of less than -1.5 MPa water potential. The samples were overnight wetted by capillary rise, then transferred on the top of a nest of four sieves of 4.75,2, 1 and $0.25 \mathrm{~mm}$ mesh immersed in water. The nest of sieves was then vertically oscillated in water by a shaking machine with a stroke of $4 \mathrm{~cm}$ per $5 \mathrm{~min}$, at a rate of 30 complete oscillations per minute. The mass of ovendried particles $\left(105^{\circ} \mathrm{C}\right.$ for $\left.24 \mathrm{~h}\right)$ that resisted breakdown was assessed for each sieve. The mass of the fraction passing through the $0.25 \mathrm{~mm}$ sieve was thus obtained by difference. The respective dry masses were used to compute MWD using the following formula 4 (Van Bavel, 1949):

$$
M W D=\sum_{j=1}^{n} W(j) \bar{x}(j)
$$

where $\bar{X}(j)$ is the arithmetic mean diameter of the $j-1$ and $\mathrm{j}$ sieve openings $(\mathrm{mm}), W(j)$ is the proportion of the total sample weight occurring in the fraction (dimensionless) and $n$ is the number of size fractions (in this case 5). Nine replicates determinations were made on each sample.

\section{Statistical analysis}

Statistical descriptive parameters and boxplots were used to characterize the distribution of input data for each site with $R$ ( $R$ Development Core Team, 2008). Differences between the two groups (no tilth and tilth) for each site (Table 1) were evaluated using the ttest to compare the means for homogeneous variances (ABP_FAG, CER, FLC, RPS) and non-homogeneous variances (ABP_VIC, AAM). HYDROLOGIC CHARACTERIZATION FOR AP HORIZON - AAM FARM

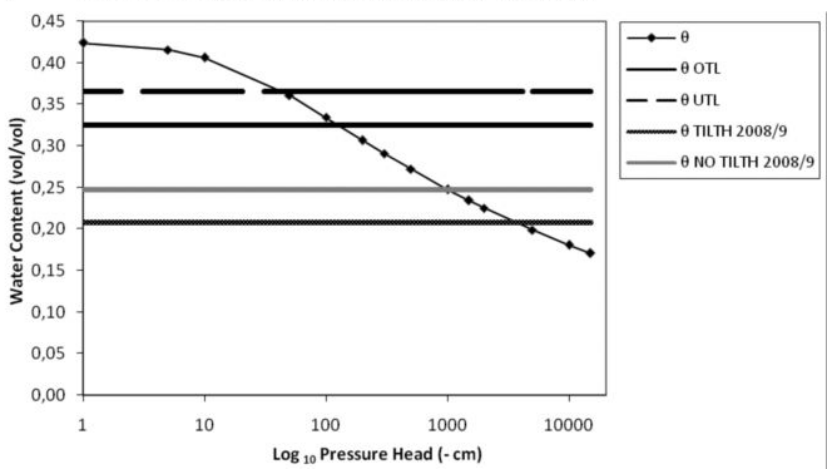

C) HYDROLOGICAL CHARACTERIZATION FOR AP HORIZON - RPS FARM

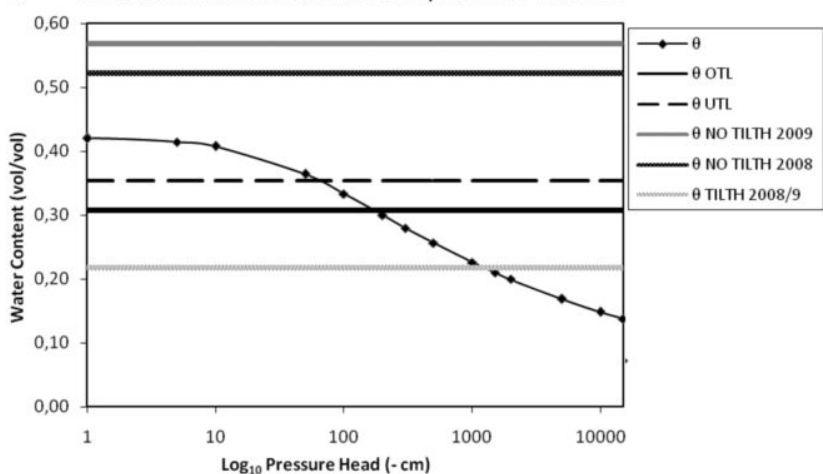

\section{Results and Discussion}

\section{Water retention curve and hydrological characterization}

Results of physical and hydrological characterization obtained by combining measures of water contents at different water potential and application of van Genuchten pedo-fuctions are showed as example in Figure 1. Each figure shows the water retention curve of the Ap horizon, the $\theta_{\text {ОтL }}$ and $\theta_{\text {UTL }}$ limits and the water content at no tilth and

Table 1. General statistical analysis for MWD and significance (in italics) of the t-test $(P<0.05)$ for the two theses.

\begin{tabular}{lcccccc} 
Site/plot & n & Mean & Median & St. Dev. & St. err. & P \\
ABP_NT_VIC & 20 & 4.82 & 4.81 & 0.50 & 0.11 & 0.00279 \\
ABP_T_VIC & 22 & 3.87 & 4.56 & 1.25 & 0.27 & \\
ABP_NT_FAG & 58 & 4.28 & 4.36 & 0.66 & 0.09 & 0.01223 \\
ABP_T_FAG & 19 & 3.86 & 3.97 & 0.80 & 0.18 & \\
\hline CER_NT & 16 & 0.50 & 0.52 & 0.10 & 0.03 & 0.01680 \\
CER_T & 8 & 0.33 & 0.32 & 0.04 & 0.01 & \\
AAM_NT & 60 & 0.94 & 0.94 & 0.34 & 0.04 & $5 \times 10^{-7}$ \\
AAM_T & 57 & 1.23 & 1.22 & 0.43 & 0.06 & \\
\hline FLC_NT & 17 & 1.71 & 1.71 & 0.27 & 0.07 & 0.31620 \\
FLC_T & 27 & 1.76 & 1.77 & 0.50 & 0.10 & \\
RPS_NT & 73 & 1.18 & 1.03 & 0.55 & 0.06 & 0.36260 \\
RPS_T & 56 & 1.10 & 0.95 & 0.54 & 0.07 & \\
\hline
\end{tabular}

NT, no tilth; T, tilth.
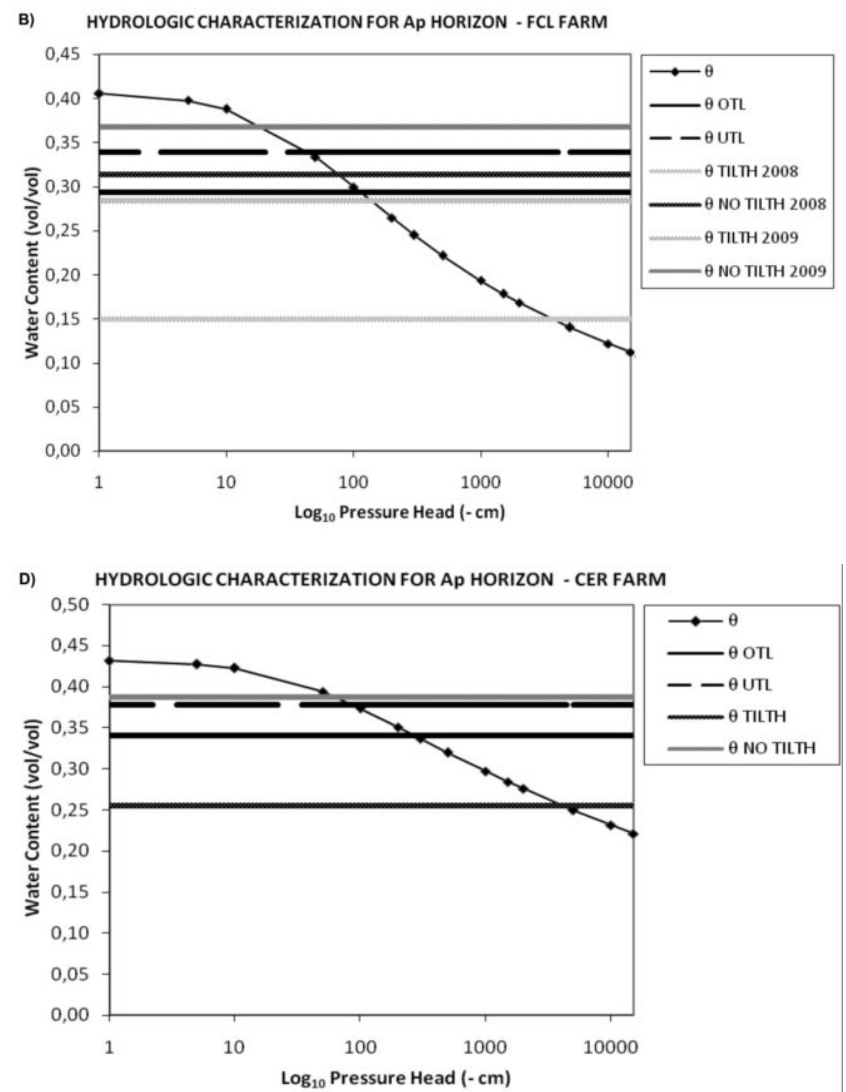

Figure 1. Soil water retention curve, optimum tillage and upper tillage limits, and water content at experimental ploughing conditions (tilth and no tilth). A) AAM Farm (Campidano Plain, Sardinia); B) FLC Farm (Po Plain, Lombardy); C) RPS Farm (Volcanic Tuff plateau, Latium); D) CER Farm (Fluvio-lacustrine Plain, Apulia). 
tilth experimental conditions, in a graph representing pressure head (cm) vs water content $\left(\mathrm{m}^{3} \mathrm{~m}^{-3}\right)$. The examples reported in Figure 1 show that the tilth and no tilth conditions are very difficult to be established only by an empirical and visual way, since the measured levels of water contents did not always correspond to conditions under and over the Optimum and Upper tillage limit. Indeed for the experimental plot in Sanluri Farm (AAM), the soil moisture contents in both the no tilth (2008 and 2009) and the tilth condition did not differ. The same case occurs for the no tilth condition during the 2008 ploughing in the Lodi Farm (FLC), where the soil water content value was rather below the calculated Upper Tillage Limit.

The OTL and UTL limits can differ widely, depending on soil physical, mineralogical and macro morphological characteristics, such as the texture class, the soil aggregates size, shape and strength, the clay type, the macropore and/or voids arrangement, the total porosity, the bulk density and packing density ${ }^{3}$ (Hall et al., 1977).

The data related to the variation of all these physical and hydrological characteristic parameters according to the different soil taxonomic unit (Soil Survey Staff, 1999) are reported in Table 2.

The water contents at optimum and upper tillage limits seems here to be strongly related to the textural composition and to the packing density, with the lowest values for sandy loam and silty loam classes and medium packing density (1.40-1.75) and the highest values for clay loam and clay texture classes and high packing density ( $>1.75)$.

\section{Wet sieving aggregate stability}

The comparison of MWD values in tilth and no tilth theses showed statistically significant differences in most cases (Table 1). In particular, mean values were the highest in the no tilth theses of the two ABP farms, where clay content is predominant. Strong correlation between soil structure stability and silt and clay content was previously observed and reported by other authors (Kemper et al., 1987; Watts et al., 1996), due to the cementing action played by colloidal components and soil organic matter.

The results of wet sieving MWD determination according to the two different tilth and no tilth conditions are reported also as box and whiskers plots in Figure 2. Two different trends, depending on the textural class of the topsoil of the experimental areas, are well represented.

On clay (ABP F), silty clay (ABP V), and clay loam (CER) topsoils we have a general and significant increase of MWD values under no tilth conditions.

${ }^{3}$ Packing density $=$ Bulk density +0.009 Clay $\%$
For the AAM sandy clay loam topsoil, the observed decrease cannot be considered representative of the different soil moisture ploughing conditions, because of the similar water contents measured and already discussed. The FLC sandy loam topsoil shows, on the opposite, decreasing values of MWD under the high soil moisture content (no tilth conditions). Furthermore, the absolute values of MWD of ABP F and $A B P V$ were four times larger than the values of CER, representing the two extreme of the range; this diversity is strongly correlated to the distribution of aggregates size inside and/or outside the MWD measured range. The lower is the MWD value, the higher is the
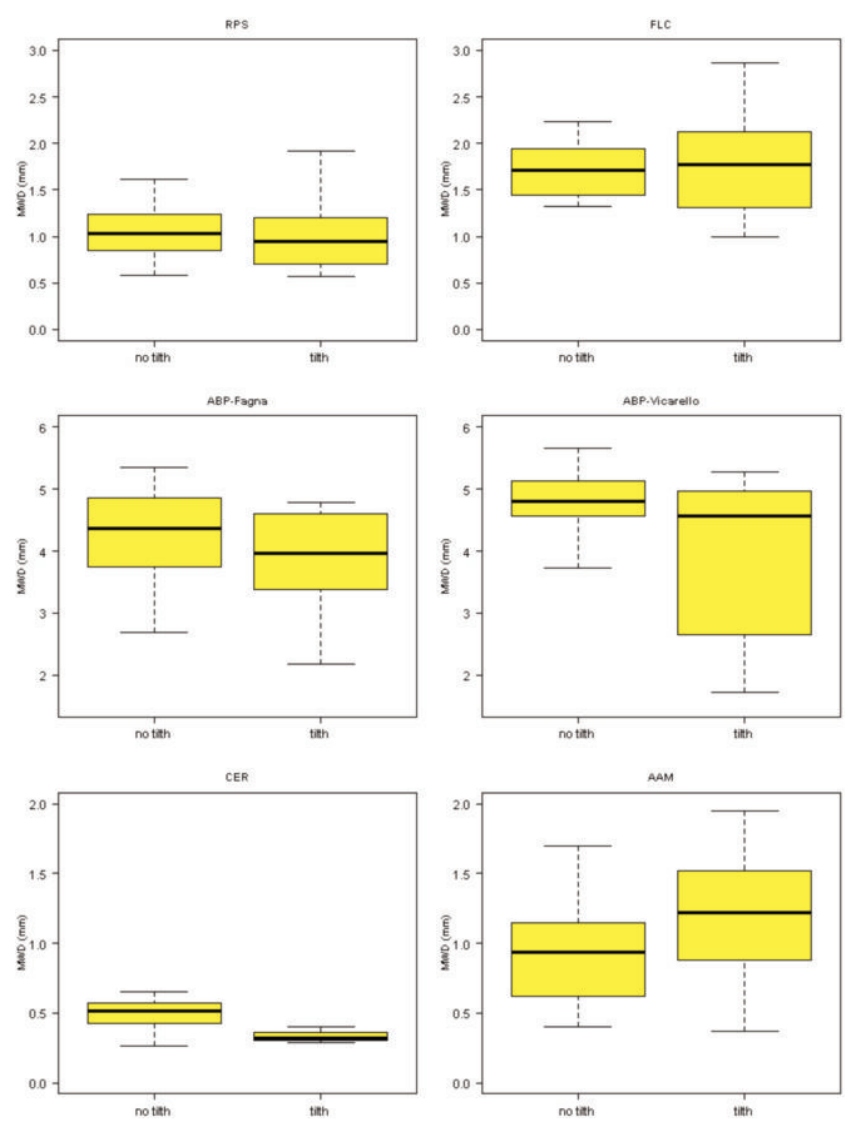

Figure 2. MWD values distribution in the different experimental sites: in the box and whiskers plots the black line in the box represents the median value, the yellow box contains $50 \%$ of the data, upper and lower whiskers are respectively the $75^{\text {th }}$ and $25^{\text {th }}$ percentile of the dataset.

Table 2. Calculated water contents at optimum and upper tillage limits (according to Dexter et al., 2001) for the different soil types of each experimental area/plot.

\begin{tabular}{|c|c|c|c|c|c|}
\hline Farm & $\begin{array}{l}\text { Soil type and } \\
\text { Ap texture }\end{array}$ & $\theta_{\text {отL }}\left(\mathrm{m}^{3} \mathrm{~m}^{-3}\right)$ & $\theta_{\text {UTL }}\left(\mathrm{m}^{3} \mathrm{~m}^{-3}\right)$ & Bulk density $\left(\mathrm{t} \mathrm{m}^{-3}\right)$ & Packing density $\left(\mathrm{t} \mathrm{m}^{-3}\right)$ \\
\hline FLC & Typic haplustalf, sandy loam & 0.294 & 0.339 & 1.49 & 1.68 \\
\hline RPS & $\begin{array}{l}\text { Entic lithic haploxeroll } \\
\text { silty loam }\end{array}$ & 0.308 & 0.353 & 1.45 & 1.66 \\
\hline $\mathrm{ABP} F$ & Aquic haplustept, clay & 0.360 & 0.396 & 1.41 & 1.89 \\
\hline ABPV & $\begin{array}{l}\text { Vertic haploxerept, } \\
\text { silty clay }\end{array}$ & 0.339 & 0.375 & 1.48 & 1.90 \\
\hline CER & Typic calcixerert, clay loam & 0.341 & 0.377 & 1.42 & 1.79 \\
\hline AAM & Vertic haploxerept, sandy clay loam & 0.325 & 0.365 & 1.45 & 1.75 \\
\hline
\end{tabular}


weight of the mean diameter measured in the small size classes of 10.25 and $>0.25 \mathrm{~mm}$ (Figure 3 ).

The not significant differences measured on FLC and RPS values, according to the Turkey test (Table 1), seems to be related to the weak soil structure characterising those topsoils. Possible explanations are: i) the very low clay content in the FLC topsoil, with a natural weak structure and low cohesion. In sandy and sandy loam soils this is a quite common condition; the micro-structure is formed by singlegrain linked by clay bridges, and soil have not any plastic behaviour. Ploughing at high soil moisture levels can rather break down the already weak bonds among the particles; ii) the nature of clay and minerals in the volcanic soil (RPS). In this case we have a weak structure although the silty loam texture. We can suppose that the zeolite presence and the clay types (halloysite and amorphous allophanic compounds) could have an influence on the soil structure formation.

\section{Field observations and agronomical data}

In the experimental farms various field observations were carried out concerning soil clods formation, plant emergence and yield. Following a selection of the observed results is reported. In the ABP soils it was observed that ploughing at soil water contents higher than the UTL values favoured soil compaction and the formation of high dimension clods (Figure 4), which in turns exerts an unfavourable action on soil microbial activity and fertility. Difference on massive structure and compaction of macro-aggregates formed on tilth and no tilth plots were also observed in CER soil (Figure 5); in

A)

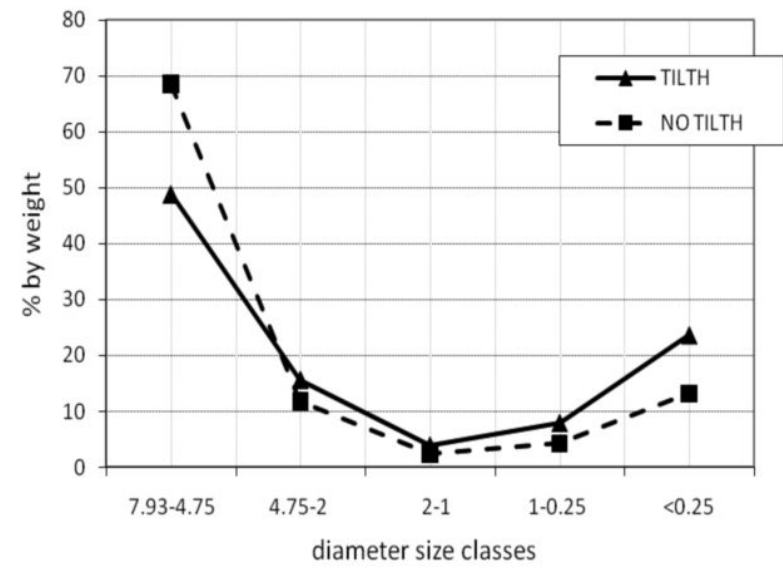

B)

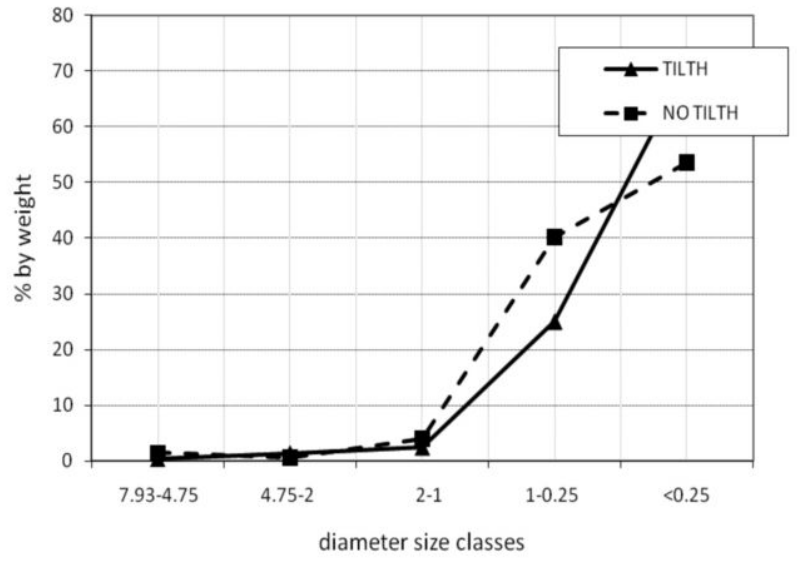

Figure 3. Aggregate size distribution for tilth and no-tilth conditions. A) ABP V Farm; B) CER Farm.

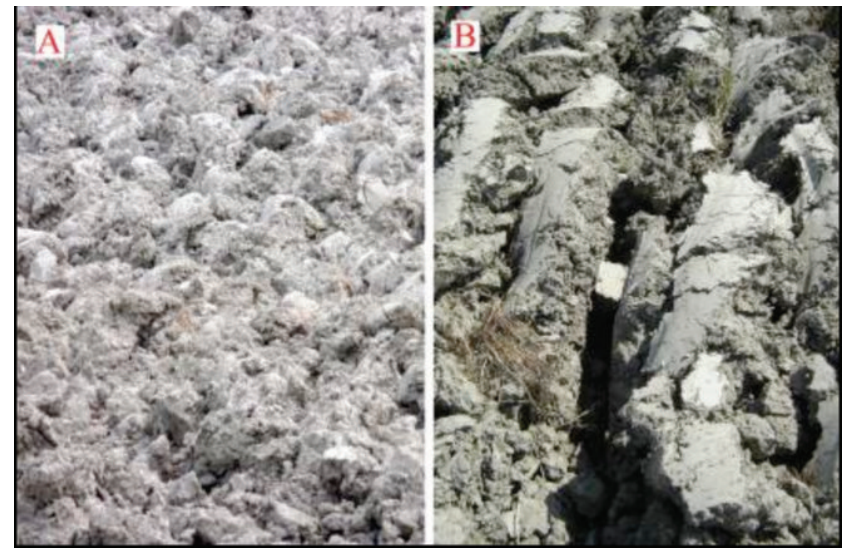

Figure 4. Effects on clods dimensions exerted by ploughing at tilth (A) or no tilth (B) soil water condition in the ABP soil.

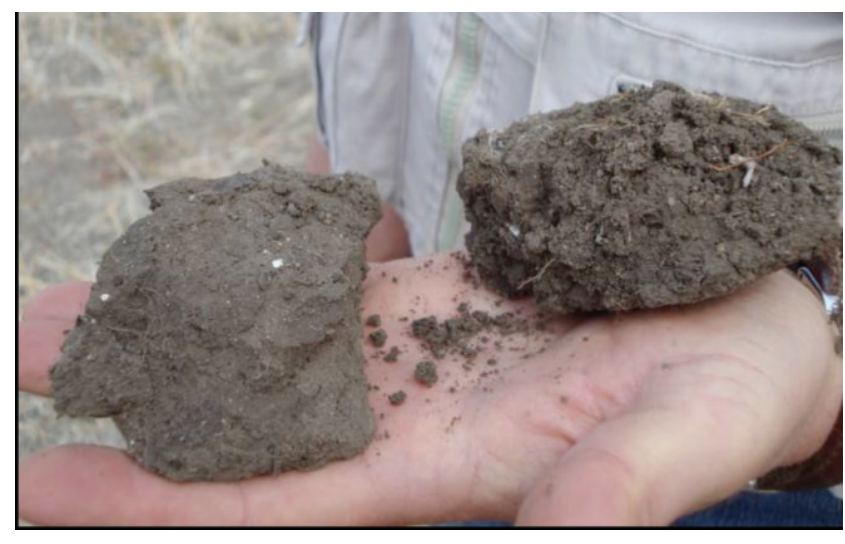

Figure 5. Effects on macro-aggregates by ploughing at tilth (right) or no tilth (left) soil water condition in the CER soil.
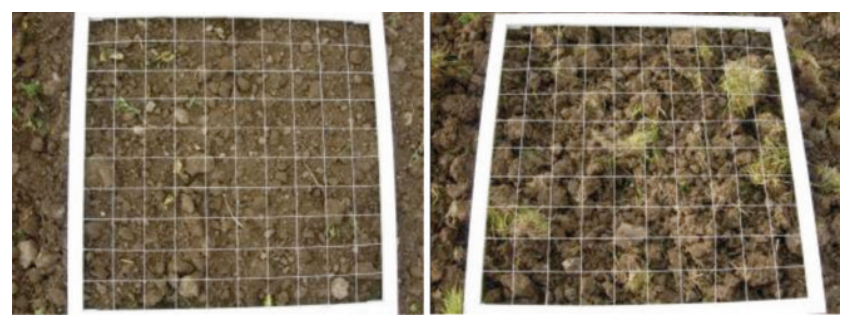

Figure 6. RPS farm. Left: seed-bed resulting from summer tillage and autumn harrowing. Right: seed-bed resulting from autumn tillage (excess of moisture - no tilth) and harrowing. Mesh size: $0.01 \mathrm{~m}^{2}$.
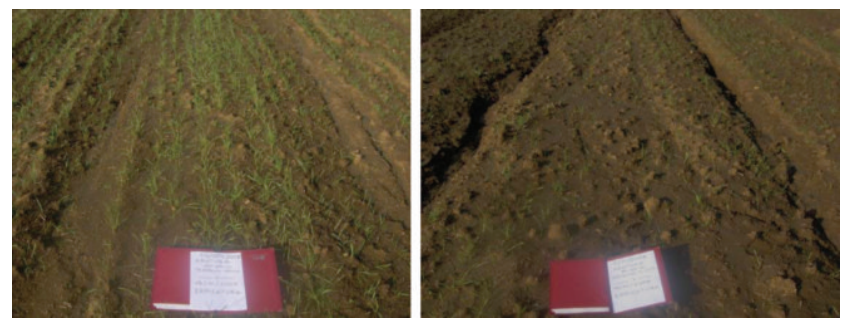

Figure 7. Effect of rainfall on plants emergence and run-off in tilth (left) and no tilth (right) plots of RPS farm. 
particular in the macro-aggregates formed in the tilth plot a higher presence of roots is visible. Figure 6 shows the clod size as a result of ploughing and harrowing at RPS farm on dry soil (in summer) and at no tilth condition in autumn. Moreover, it was observed that ploughing at very high soil water content enhanced erosion processes due to water runoff in the no tilth plots, which negatively impacted also on plant emergence, as shown in the picture of Figure 7.

A significant weeds control was also obtained in most farms in the tilth plots, as shown in Figure 8 for RPS farm, and on plants emergence as in Figure 9 for FLC farm.

A positive effect was exerted on crop data by ploughing at optimum soil water contents, as shown in Table 3 . Higher number of plant emerged, lower weeds development and higher yields were observed in plots ploughed at the tilth conditions, representing an additional positive goal at agronomical level.

Table 3. Effect of tilth and no tilth conditions on crop parameters.

\begin{tabular}{|c|c|c|c|}
\hline Farm & Treatment & Parameter & Mean \\
\hline \multirow[t]{7}{*}{ RPS } & $\begin{array}{c}\mathrm{NT} \\
\mathrm{T}\end{array}$ & Winter wheat emergence (seedlings $\mathrm{m}^{-2}$ ) & $\begin{array}{l}185.25 \\
291.10\end{array}$ \\
\hline & NT & \multirow[t]{2}{*}{ Monocotyledonous weeds $\left(\mathrm{t} \mathrm{ha}^{-1}\right)$} & 0.64 \\
\hline & $\mathrm{T}$ & & 0.19 \\
\hline & NT & \multirow[t]{2}{*}{ Wheat spikes (spikes $\mathrm{m}^{-2}$ ) } & 183.25 \\
\hline & $\mathrm{T}$ & & 260.00 \\
\hline & NT & \multirow[t]{2}{*}{ Wheat yield $\left(\mathrm{t} \mathrm{ha}^{-1}\right)$} & 2.23 \\
\hline & $\mathrm{T}$ & & 3.27 \\
\hline \multirow[t]{12}{*}{ AAM } & NT & \multirow[t]{2}{*}{ Winter wheat emergence (seedlings $\mathrm{m}^{-2}$ ) } & 85.33 \\
\hline & $\mathrm{T}$ & & 165.30 \\
\hline & NT & \multirow{2}{*}{ Wheat spikes (spikes $\mathrm{m}^{-2}$ ) } & 64.83 \\
\hline & $\mathrm{T}$ & & 248.18 \\
\hline & NT & \multirow[t]{2}{*}{ Wheat yield $\left(\mathrm{t} \mathrm{ha}{ }^{-1}\right)$} & 0.14 \\
\hline & $\mathrm{T}$ & & 0.58 \\
\hline & NT & \multirow[t]{2}{*}{ Pea emergence (seedlings $\mathrm{m}^{-2}$ ) } & 10.65 \\
\hline & $\mathrm{T}$ & & 54.65 \\
\hline & NT & \multirow[t]{2}{*}{ Clover yield $\left(\mathrm{t} \mathrm{ha}^{-1}\right)$} & 35.61 \\
\hline & $\mathrm{T}$ & & 37.55 \\
\hline & NT & \multirow[t]{2}{*}{ Clover straw $\left(\mathrm{t} \mathrm{ha}^{-1}\right)$} & 2.43 \\
\hline & $\mathrm{T}$ & & 2.48 \\
\hline \multirow[t]{20}{*}{ FLC } & NT & \multirow[t]{2}{*}{ Wheat emergence (seedlings $\mathrm{m}^{-2}$ ) } & 254.91 \\
\hline & $\mathrm{T}$ & & 390.48 \\
\hline & NT & \multirow[t]{2}{*}{ Wheat grain $\left(\mathrm{t} \mathrm{ha}^{-1}\right)$} & 2.79 \\
\hline & $\mathrm{T}$ & & 4.23 \\
\hline & NT & \multirow[t]{2}{*}{ Wheat straw (\% dw) } & 89.83 \\
\hline & $\mathrm{T}$ & & 90.23 \\
\hline & NT & \multirow[t]{2}{*}{ Wheat straw $\left(\mathrm{t} \mathrm{ha}^{-1}\right)$} & 4.89 \\
\hline & $\mathrm{T}$ & & 5.94 \\
\hline & NT & \multirow[t]{2}{*}{ Wheat grain $\left(\mathrm{t} \mathrm{ha} \mathrm{a}^{-1}\right)$} & 3.20 \\
\hline & $\mathrm{T}$ & & 3.82 \\
\hline & NT & \multirow[t]{2}{*}{ Wheat weight $\left(\mathrm{kg} \mathrm{hl}^{-1}\right)$} & 72.25 \\
\hline & $\mathrm{T}$ & & 73.78 \\
\hline & NT & \multirow[t]{2}{*}{ Wheat grain $\left(\mathrm{t} \mathrm{ha}^{-1}\right)$} & 2.79 \\
\hline & $\mathrm{T}$ & & 4.23 \\
\hline & NT & \multirow[t]{2}{*}{ Wheat straw $\left(\mathrm{t} \mathrm{ha}^{-1}\right)$} & 4.39 \\
\hline & $\mathrm{T}$ & & 5.37 \\
\hline & NT & \multirow[t]{2}{*}{ Wheat harvest index } & 0.39 \\
\hline & $\mathrm{T}$ & & 0.44 \\
\hline & NT & \multirow[t]{2}{*}{ Wheat weeds (\% of plants per plot) } & 1.50 \\
\hline & $\mathrm{T}$ & & 7.00 \\
\hline \multirow[t]{2}{*}{ ABP } & NT & \multirow[t]{2}{*}{ Winter wheat grain $\left(\mathrm{t} \mathrm{ha}^{-1}\right)$} & 4.00 \\
\hline & $\mathrm{T}$ & & 3.30 \\
\hline
\end{tabular}

Values in italics are significantly different $(\mathrm{P}<0.05)$.

\section{Conclusions}

After two years of survey on the experimental plots a first positive evaluation of the effectiveness of the GAEC cross-compliance Standard Ploughing in good soil moisture conditions could be stated. Significant differences were observed in the aggregate stability among different topsoil texture classes, and the two main theses of tilth and no tilth conditions, according to the soil structure protection main goal. Ploughing in good soil moisture condition led to less soil compaction than ploughing in high moisture condition, for clay, clay loam, silty clay, and silty clay loam topsoils. No significant differences between treatments were observed on silt loam and sandy loam topsoils. For sandy loam soils the sand/clay ratio seems to be a good indicator to identify a texture threshold to define the effectiveness of the GAEC standard, and the same effectiveness evaluation could be reasonably extended to the coarser classes of loamy sand and sand. The case of silt loam soils on volcanic tuff indicates that the mineralogical types of the silt and clay fractions could represent an important factor in controlling the plastic behaviour and the structure conservation, but further and specific studies about the cause of negative response inside the soil developed on effusive volcanic parent materials are required. Other important positive results were obtained also from the agronomical point of view, since in the experimental plots ploughing in good soil moisture condition determined higher crop production and less weed development than ploughing in high soil moisture conditions.

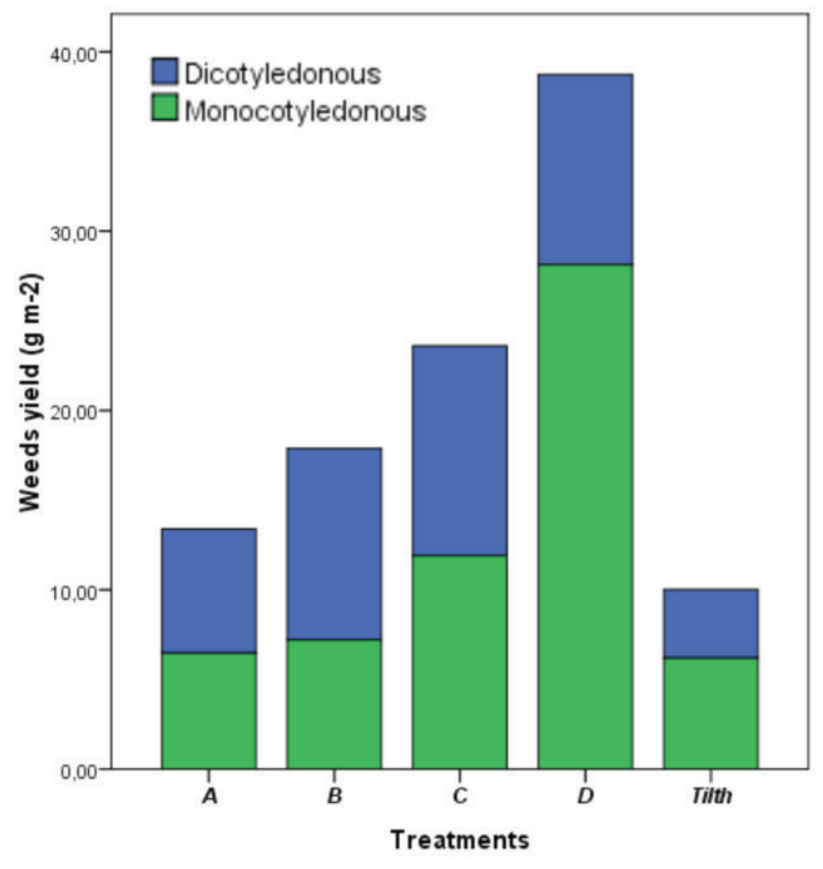

Figure 8. RPS farm: weeds yield $\left(\mathrm{g} \mathrm{m}^{-2}\right)$ at end of trial. The plots from $A$ to $D$ were ploughed at increasing water contents (no tilth).

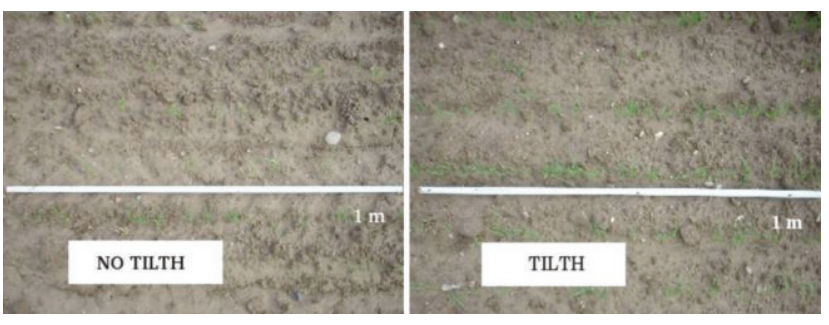

Figure 9. Plants emergence in FLC farm. 


\section{References}

Armenise E., Stellacci A. M., Caliandro A., 2008. Indici di qualità: come condensare in un unico numero lo status quo di un suolo. Atti $1^{\circ}$ Congr. Naz. Qualità del Suolo, Alimenti e Salute, Palermo, Italy. Biologi Italiani, 4/2008, pp 4-9.

Bagarello V., Castellini M., Iovino M., Sgroi A., 2009. Indagine sulla qualità fisica di alcuni suoli siciliani. Atti $9^{\circ}$ Convegno Naz. Associazione Italiana di Ingegneria Agraria, Ischia Porto, Napoli, Italy, memoria n. 3-46.

Bonciarelli F., 1981. Agronomia. Ed. Edagricole, Bologna, Italy.

Borrelli L., Tomasoni C., 2005. Nota sulle caratteristiche pedo-climatiche dell'azienda dell'Istituto Sperimentale per le Colture Foraggere di Lodi. Annali Istituto Sperimentale per le Colture Foraggere 9:43-49.

Brady N.C., 1984. The Nature and Properties of Soils, 9th ed. Macmillan Publ., New York, NY, USA.

Dexter A.R., 2004a. Soil physical quality Part I. Theory, effects of soil texture, density, and organic matter, and effects on root growth. Geoderma 120:201-214.

Dexter A.R., 2004b. Soil physical quality: Part II. Friability, tillage, tilth and hard-setting. Geoderma 120:215-225.

Dexter A.R., 2004c. Soil physical quality Part III: Unsaturated hydraulic conductivity and general conclusions about S-theory. Geoderma 120:227-239.

Dexter A.R., Bird N.R.A., 2001. Methods for predicting the optimum and the range of soil water contents for tillage based on the water retention curve. Soil Till. Res. 57:203-212.

Dexter A.R., Birkas M., 2004. Prediction of the soil structures produced by tillage. Soil Till. Res. 79:233-238.

Dexter A.R., Czyz E.A., 2007. Application of S-theory in the study of soil physical degradation and its consequence. Land Degrad. Dev., 18:369-381.

Dexter A.R., Czyz E.A., Birkas M., Diaz-Pereira E., Dumitru E., Enache R., Fleige H., Horn R., Rajkaj K., de la Rosa D., Simota C., 2005. SIDASS project Part 3. The optimum and the range of water content for tillage - further developments. Soil Till. Res. 82:29-37.

Dexter, A.R., Richard, G. 2009. Tillage in soils in relation to their bimodal pore size distributions. Soil Till. Res. 103:113-118.

Dexter A.R., Richard G., Arrouays D., Czyz E.A., Jolivet C., Duval 0. 2008. Complexed organic matter controls soil physical properties. Geoderma 144:620-627.

Hall D.G.M., Reeve M.J., Thomasson A.J., Wright V.F., 1977. Water retention, porosity, and density of field soils. Soil Survey Technical Monograph No. 9, Harpenden, UK.

Hoogmoed W.B., 1985. Soil tillage at the tropical agriculture day. Soil Till. Res. 5:315-316.

Kay B.D., Hajabbasi M.A., Ying J., Tollenaar M., 2006. Optimum versus non-limiting water contents for root growth, biomass accumulation, gas exchange and the rate of development of maize (Zea mays L.). Soil Till. Res. 88:42-54.

Keller T., Arvidsson J., Dexter A.R., 2007. Soil structures produced by tillage as affected by soil water content and the physical quality of soil. Soil Till. Res. 92:45-52.

Kemper W.D., Rosenau R.C. 1986. Aggregate stability and size distribution. In: Methods of soil Analysis, Part I. Physical and Mineralogical methods. Agronomy Monograph no. 9, 2nd ed. American Society of Agronomy -Soil Science Society of America, Madison, WI, USA, pp 425-442.

Kemper W.D., Rosenau R.C., Dexter A.R., 1987. Cohesion development in disrupted soils as affected by clay and organic matter content and temperature. Soil Sci. Soc. Am. J. 51:860-867.

Kretschmer H., 1996. Konsistenz und Körnung. Handbuch der
Bodenkunde. Böden als Baugrund und Baustoff. Chapter 2.6.1.1 In: H.P. Blume, P. Felix-Henningsen, W.R. Fischer, H.G. Frede, R. Horn and K. Stahr (eds.), Handbuch der Bodenkunde, vol. 1, 1st ed., Ecomed Verlagsgesellschaft Ed., Landsberg, Germany.

Le Bissonnais Y., 1996. Aggregate stability and assessment of soil crustability and erodibility: Theory and methodology. Eur. J. Soil Sci. 47:425-437.

Ministero delle Politiche Agricole Agroalimetari e Forestali, 1997a. Metodi Ufficiali di Analisi Fisica del Suolo. Determinazione della massa volumica apparente. Metodo II.1.3.1. del carotaggio. Coordinatore M. Pagliai. Franco Angeli ed., Milano, Italy, pp. 4-6

Ministero delle Politiche Agricole Agroalimetari e Forestali, 1997b. Metodi Ufficiali di Analisi Fisica del Suolo. Ritenzione Idrica. Metodo VIII.3.3.1. dell'apparato a pressione e della cassetta tensiometrica. Coordinatore m. Pagliai. Franco Angeli ed., Milano, Italy, pp 58-65.

Mualem Y. ,1976. A new model for predicting the hydraulic conductivity of unsaturated porous media. Water Resour. Res. 12:513-522.

Mueller L., Schindler U., Fausey N.R., Lal R., 2003. Comparison of methods for estimating maximum soil water content for optimum workability. Soil Till. Res. 72:9-20.

Mueller W., 1985. Standortkundliche Voraussetzungen fuer die Gefuegemelioration durch Tieflockerung im humiden Klima. pp 1-34 in: Die Gefuegemelioration durch Tieflockerung - Bisherige Erfahrungen und Ergebnisse Schriftenreihe des Deutschen Verbandes fuer Wasserwirtschaft und Kulturbau e.V. (DVWK) Heft Nr. 70. Verlag Paul Parey, Hamburg und Berlin, Germany.

Plaster E.J., 1985. Soil Science and Management. Delmar Publ., Albany, NY, USA.

R Development Core Team, 2008. R: A language and environment for statistical computing. R Foundation for Statistical Computing, Wien, Austria. Available from: -http://www.R-project.org. Last access: march 2011.

Rohošková M., Valla M., 2004. Comparison of two methods for aggregate stability measurement - a review. Plant Soil Environ. 50:379382.

Schjønning P., Munkholm L.J., Elmholt S., Olesen J.E., 2007. Organic matter and soil tilth in arable farming: management makes a difference within 5-6 years. Agr. Ecosyst. Environ. 122:157-172.

Singh K.K., Colvin T.S., Erbach D.C., Mughal A.Q., 1992. Tilth index: an approach to quantifying soil tilth. Trans. ASABE 35:1777-1785.

Soil Survey Staff, 1999. Soil taxonomy: a basic system of soil classification for making and interpreting soil surveys (2nd ed.). US Department of Agriculture Soil Conservation Service Publ., Washington, DC, USA.

SSSA, 1979. Glossary of soil science terms. Soil Science Society of America Publ., Madison, WI, USA.

Tripathi R.P., Sharma P., Singh S., 2005. Tilth Index: an approach to optimize tillage in rice-wheat system. Soil Till. Res. 80:125-137.

van Bavel C.H.M., 1949. Mean weight diameter of soil aggregates as a statistical index of aggregation. Soil Sci. Soc. Am. Pro. 14:20-23.

van Genuchten M.Th.. 1980. A closed-form equation for predicting the hydraulic conductivity of unsaturated soils. Soil Sci. Soc. Am. J. 44:892-898.

van Genuchten M.Th., Leij F.J., Yates S.R., 1991. The RETC Code for Quantifying the Hydraulic Functions of Unsaturated Soils. Environmental Protection Agency Report n. EPA/600/2-91/065.

Watts C.W., Dexter A.R., Dumitru E., Arvidsson J., 1996. An assessment of the vulnerability of soil structure to destabilisation during tillage. Part I. A laboratory test. Soil Till. Res. 37:161-174.

Wösten J.H.M., Lilly A, Nemes A., Le Bas C. ,1999. Development and use of a database of hydraulic properties of European soils. Geoderma 90:169-185. 